\title{
EVALUATION OF GASTRIC HISTOLOGY IN CHILDREN AND ADOLESCENTS WITH HELICOBACTER PYLORI GASTRITIS USING THE UPDATE SYDNEY SYSTEM
}

\author{
Marini LANGNER ${ }^{1}$, Rodrigo S. MACHAD0¹, Francy R. S. PATRÍCIO² and Elisabete KAWAKAMI'
}

\begin{abstract}
Context - Although Helicobacter pylori infection is prevalent in our country, there are few studies evaluating the associated histological abnormalities in children. Objective - To evaluate the histological features of the gastric mucosa in children and adolescents with Helicobacter pylori gastritis. Methods - One hundred and thirty two gastric biopsies from 22 symptomatic patients infected with H. pylori (14F/8M, median age 10 y $5 \mathrm{mo}$, age range 2 y 11 mo to 16 y $9 \mathrm{mo})$ were evaluated. Evaluated gastric regions included: antrum (lesser and greater curvature), corpus (lesser and greater curvature), incisura angularis and fundus. Histological examination was performed according to the Updated Sydney System, and regional scores for polymorphonuclear and mononuclear cell infiltrate as well as bacterial density were generated. Results - Fifteen (68.2\%) patients presented H. pylori-chronic active gastritis, six $(27.3 \%)$ presented antrum-predominant $H$. pylori-chronic active gastritis, and one (4.5\%) presented corpus-predominant $H$. pylori-chronic active gastritis. Polymorphonuclear cell infiltrate and mononuclear cell infiltrate were observed in $93.9 \%$ and $98.5 \%$ of the biopsy specimens, respectively. Higher histological scores for polymorphonuclear infiltrate, mononuclear infiltrate, and bacterial density were observed in the gastric antrum. Intestinal metaplasia and gastric atrophy were not identified in any patient. Lymphoid aggregates and lymphoid follicles were observed in the gastric antrum of three (13.6\%) and seven (31.8\%) patients, respectively, but they were not related to antral nodularity. Conclusions - Chronic active gastritis was observed in all patients with H. pylori infection. However, antral or corporeal predominance was not observed in most patients.
\end{abstract}

HEADINGS - Gastritis, classification. Helicobacter infections. Gastric mucosa. Adolescent. Child.

\section{INTRODUCTION}

The Helicobacter pylori is a pathogen which is highly adapted to the gastric mucosa, where it causes gastritis in all infected individuals. Indeed, gastritis is of paramount importance to the survival of the bacteria on the gastric mucosa surface because the inflamed mucosa releases nutrients and substrates into the gastric lumen, which are needed to the bacterial metabolism and its adaptation to the gastric environment ${ }^{(1)}$. $H$. pylori gastritis is associated with long term morbidity, such as peptic ulcer and gastric neoplasm. Typically, the infection is acquired during infancy, but it remains silent in most patients until adulthood. Its long-term consequences depend on the phenotype of the infected individual, and three phenotypes have been identified: 1) mild pangastritis, with little disruption of gastric acid secretion (good prognosis); 2) antral-predominant gastritis, with relative sparing of the acid-producing corpus (duodenal ulcer-associated phenotype); and 3) corpus-predominant gastritis, with multifocal gastric atrophy and hypo- or achlorhydria (gastric cancerassociated phenotype) $)^{(2)}$.

Helicobacter pylori gastritis has unique features in children, such as the nodular aspect of the gastric antrum, antral predominance of gastritis in most patients, and uncommon diagnosis of gastric atrophy and intestinal metaplasia. Nevertheless, sulphomucincontaining cells have been described in the gastric mucosa of $H$. pylori infected children, suggesting that incomplete intestinal metaplasia (type III) can develop even during childhood and evolve into complete intestinal metaplasia in adults ${ }^{(6)}$.

The Updated Sydney System has provided guidelines for classifying, grading and reporting on endoscopic and histological assessment of gastric mucosa ${ }^{(7)}$. Because it is clear that the extent and distribution of the $H$. pylori gastritis determine the clinical outcome, the Updated Sydney System emphasizes the importance of combining topographical, morphological, and

Institution: Pediatric Gastroenterology Division, Department of Pediatrics, UNIFESP/EPM, São Paulo, SP, Brazi .

1 Pediatric Gastroenterology Division, Department of Pediatrics, "Universidade Federal de São Paulo / Escola Paulista de Medicina" (UNIFESP/EPM); ${ }^{2}$ Department of Pathology, UNIFESP/EPM;

Correspondence: Dr. Rodrigo Strehl Machado - Rua Pedro de Toledo, 441 - 04039-001, São Paulo, SP, Brazil. E-mail: rodrigo@gastroped.epm.br 
etiological information in order to generate diagnosis ${ }^{(7)}$. However, the system was developed for adult patients, who frequently present H.pylori-related gastric atrophy and metaplasia, which ought to be differentiated from other etiologies. In order to enhance the identification of preneoplastic lesions, the Updated Sydney System has added a biopsy from the incisura angularis to the panel, but intestinal metaplasia can still be missed in up to $25 \%$ of patients ${ }^{(8)}$. Modifications have been proposed to the report of chronic gastritis in order to simplify it and provide some prognostic information ${ }^{(21)}$.

The aim of this study was to evaluate the histological features of $H$. pylori gastritis in children, using the Updated Sydney System. A fundic biopsy was added to the panel in order to evaluate all gastric regions.

\section{METHODS}

A total of 132 gastric biopsies from 22 symptomatic patients infected with $H$. pylori $(14 \mathrm{~F} / 8 \mathrm{M}$, median age $10 \mathrm{y}$ 5 mo, age range from 2 y 11 to 16 yrs 9 mo) were evaluated. Patients were screened during upper digestive endoscopy with the rapid urease test. Exclusion criteria were celiac disease, idiopathic inflammatory bowel disease and usage of medications $\left(\mathrm{H}_{2}\right.$ histaminic-blockers, antimicrobials, proton pump inhibitors or bismuth salts) in the previous month. The study was approved by the Ethics in Research Committee of the Universidade Federal de São Paulo - Escola Paulista de Medicina, São Paulo, SP, Brazil. Parents or legal guardians were informed about the study protocol and invited to sign an informed consent.

Endoscopy. Esophagus, stomach, and proximal duodenal mucosa were examined under sedation or general anesthesia. Six biopsies of the gastric mucosa: two from gastric corpus (lesser and greater curvature), two from gastric antrum (lesser and greater curvature), one from the incisura angularis and the last one from gastric fundus were collected for histological examination. Two biopsy fragments were further collected from the gastric antrum approximately $2 \mathrm{~cm}$ from the pylorus for the rapid urease test (RUT), which was performed with a non-commercial solution $(100 \mathrm{mg} / \mathrm{mL}$ aqueous urea solution with $10 \mathrm{mg} / \mathrm{mL}$ phenol red) ${ }^{(18)}$.

Histological evaluation. The fragments were placed on filter paper and fixed in $100 \mathrm{~mL} / \mathrm{L}$ formaldehyde. Twenty serial sections of $6 \mu \mathrm{m}$ were prepared per fragment and stained with hematoxylin-eosin and modified Giemsa. H.pylori infection was diagnosed based on the typical appearance of the bacterium along the mucus layer covering the gastric mucous membrane. Histological evaluation was performed according to the Updated Sydney System ${ }^{(7)}$. The histological variables (mononuclear infiltrate, neutrophilic infiltrate, bacterial density, intestinal metaplasia, and gastric atrophy) were graded according to the Updated Sydney System visual analogue scale to generate a score $(0=$ absent, $1=$ mild, $2=$ moderate and $3=$ marked $)$. Eosinophils were registered when present, and its count was reported as the highest count observed by high power field.
Lymphoid aggregates and lymphoid follicles were counted when present. The patient was considered infected when both the rapid urease test and histological examination provided positive results.

Statistics. Discrete variables were described by their medians and interquartile ranges, while quantitative variables were described by their means and standard deviations, and qualitative variables were described by proportions. The Kruskall-Wallis test was used to compare the scores of each gastric region, and Dunn's post-hoc test was used when the Kruskall-Wallis test was significant. Wilcoxon's test was used to compare histological regional scores according to the presence of antral nodularity, lymphoid aggregates and lymphoid follicles. In all statistical tests, a $P<0.05$ was considered significant.

\section{RESULTS}

The most frequent symptom indicating endoscopy was epigastric pain $(18 / 22,81.9 \%)$. The upper digestive endoscopy was normal in $40.9 \%(9 / 22)$ patients, and the most frequent abnormality was antral nodularity $(12 / 22,54.6 \%)$. One patient presented hyperemic gastritis $(4.5 \%)$. The histological diagnosis was antrum-predominant $H$. pylori-chronic active gastritis in 6 patients $(27.3 \%)$, corpus-predominant $H$. pylori-chronic active gastritis in 1 patient $(4.5 \%)$ and $H$. pylori-chronic active gastritis in 15 patients $(68.2 \%)$.

Mononuclear infiltrate was present in all except two biopsies $(98.5 \%)$, whereas polymorphonuclear cell infiltrate was observed in $93.9 \%(124 / 132)$ of the biopsy specimens and H.pylori was identified in $97.7 \%(129 / 132)$. In the Table 1 , the distribution of biopsy specimens according to the histological score in each gastric region is displayed.

The mononuclear infiltrate in the greater curvature of the gastric antrum was significantly more intense than that in the greater curvature of the gastric corpus $(P=0.013)$. The median scores and their interquartile range for each gastric region are depicted in the Table 2, and higher histological scores for bacterial density and polymorphonuclear cell infiltrate were observed in the greater curvature of the gastric antrum as compared with the gastric fundus. Additionally, the endoscopic diagnosis of nodular gastritis was significantly associated with both the score for neutrophilic infiltrate in the lesser curvature of the gastric antrum (median 2 and IQ range $2-2$ vs. median 1 and IQ range $1-2, P=0.017$ ), and the score for bacterial density in the gastric fundus (median 2 and IQ range $1.25-2$ vs. median 1 and IQ range $1-1.25, P=0.036)$.

Eosinophils were observed in at least one biopsy of $21 / 22$ patients $(95.5 \%)$, and the eosinophil count ranged from 1.2 to $15 \mathrm{hpf}$ (mean 5.41 - standard deviation 3.85). Lymphoid aggregates and lymphoid follicles were observed in the gastric antrum of three (13.6\%) and seven $(31.8 \%)$ patients, respectively. There was no relationship between either aggregates or follicles and antral nodularity $(P=0.57$ and $P=0.65$ ). No patients exhibited either gastric atrophy or intestinal metaplasia. 
TABLE 1. Histological scores for mononuclear cell infiltrate, polymorphonuclear cell infiltrate and bacterial density according to the gastric region in 22 patients

\begin{tabular}{|c|c|c|c|c|c|c|c|c|c|c|c|c|}
\hline & \multicolumn{4}{|c|}{ Mononuclear cell infiltrate $\mathrm{n}(\%)$} & \multicolumn{4}{|c|}{ Polymorphonuclear cell infiltrate $\mathrm{n}(\%)$} & \multicolumn{4}{|c|}{ Bacterial density $\mathrm{n}(\%)$} \\
\hline & 0 & 1 & 2 & 3 & 0 & 1 & 2 & 3 & 0 & 1 & 2 & 3 \\
\hline IA & $0(0)$ & $3(13.6)$ & $12(54.5)$ & $7(31.8)$ & $0(0)$ & $10(45.5)$ & $9(40.9)$ & $3(13.6)$ & $0(0)$ & $5(22.7)$ & $13(59.1)$ & $4(18.2)$ \\
\hline LCA & $0(0)$ & $3(13.6)$ & $10(45.5)$ & $9(40.9)$ & $1(4.5)$ & $8(36.4)$ & $11(50.0)$ & $2(9.1)$ & $0(0)$ & $5(22.7)$ & $13(59.1)$ & $4(18.2)$ \\
\hline GCA & $0(0)$ & $3(13.6)$ & $10(45.5)$ & $9(40.9)$ & $1(4.5)$ & $4(18.2)$ & $12(54.5)$ & $5(22.7)$ & $0(0)$ & $2(9.1)$ & $14(63.6)$ & $6(27.3)$ \\
\hline LCC & $0(0)$ & $5(22.7)$ & $11(50.0)$ & $6(27.3)$ & $2(9.1)$ & $13(59.1)$ & $5(22.7)$ & $2(9.1)$ & $1(4.5)$ & $9(40.9)$ & $9(40.9)$ & $3(13.6)$ \\
\hline GCC & $0(0)$ & $10(45.5)$ & $9(40.9)$ & $3(13.6)$ & $1(4.5)$ & $14(63.6)$ & $4(18.2)$ & $3(13.6)$ & $0(0)$ & $12(54.5)$ & $6(27.3)$ & $4(18.2)$ \\
\hline F & $2(9.1)$ & $6(27.3)$ & $9(40.9)$ & $5(22.7)$ & $3(13.6)$ & $14(63.6)$ & $4(18.2)$ & $1(4.5)$ & $2(9.1)$ & $9(40.9)$ & $10(45.5)$ & $1(4.5)$ \\
\hline Total & $2(1.5)$ & $30(22.7)$ & $61(46.2)$ & $39(29.5)$ & $8(6.1)$ & $63(47.7)$ & $45(34.1)$ & $16(12.1)$ & $3(2.3)$ & $42(31.8)$ & $65(49.2)$ & $22(16.7)$ \\
\hline
\end{tabular}

$\mathrm{IA}=$ incisura angularis; $\mathrm{LCA}=$ lesser curvature of gastric antrum

$\mathrm{GCA}=$ great curvature of gastric corpus; $\mathrm{LCC}=$ lesser curvature of gastric corpus;

$\mathrm{GCC}=$ great curvature of gastric corpus; $\mathrm{F}=$ gastric fundus.

Hild; 2: moderate; 3: marked

TABLE 2. Comparison of histological scores for the grades of mononuclear infiltrate, neutrophilic infiltrate and bacterial density according to the gastric region

\begin{tabular}{|c|c|c|c|}
\hline Gastric region & Mononuclear infiltrate median $\left(\mathrm{IQR}^{* *}\right)$ & Neutrophilic infiltrate median (IQR) & Bacterial density median (IQR) \\
\hline Lesser curvature of gastric antrum (LCA) & $2(2-3)$ & $2(1-2)$ & $2(2-2)$ \\
\hline Greater curvature of gastric antrum (GCA) & $3(2-3)$ & $2(2-2)$ & $2(2-3)$ \\
\hline Lesser curvature of gastric corpus (LCC) & $2(2-3)$ & $1(1-2)$ & $2(1-2)$ \\
\hline Greater curvature of gastric corpus (GCC) & $2(1-2)$ & $1(1-2)$ & $1(1-2)$ \\
\hline Incisura angularis (IA) & $2(2-3)$ & $2(1-2)$ & $2(2-2)$ \\
\hline Gastric fundus (GF) & $2(1-2)$ & $1(1-2)$ & $1.5(1-2)$ \\
\hline $\mathrm{P}$ (Kruskall-Wallis' test) & $0.013 *$ & $0.004 * *$ & $0.010 * * *$ \\
\hline
\end{tabular}

* Dunn's test: GCA>GCC; ** Dunn's test: GCA>GF; *** Dunn's test: GCA>GF;

** IQR: interquartile range

\section{DISCUSSION}

This study is the first topographical study on H. pylori gastritis in Brazilian children. Most patients presented active chronic gastritis without regional predominance, which may explain the low morbidity of the infection in the childhood, because antral-predominance and corporeal-predominance of the gastritis has been associated with duodenal ulcer and preneoplastic lesions, respectively ${ }^{(2)}$.

The study has three main shortcomings. First, the sample size was small and it may have generated a type- 2 error while comparing histological scores. However, a previous study with similar goals studied 15 patients - some of them more than once -, whereas another study compared the histological assessment of 19 infected patients to that of 45 healthy controls ${ }^{(5,11)}$. The second limitation is the method of staining used in the study, because some authors reported that staining with alcian blue-periodic acid Schiff (PAS) enhances the detection of incomplete intestinal metaplasia due to the detection of sulphated mucossubstances ${ }^{(6)}$. This is an important limitation as it could prevent the detection of incomplete intestinal metaplasia. Finally, this study did not evaluate the inter-observer reproducibility of the histological evaluation. In order to standardize the histological report, we used the visual analogue scale of the Update Sydney System. Study evaluating the reproducibility of this scale reported concordance coefficients (Kappa) as high as 0.77 when comparing two pathologists: this statistic indicates good but not perfect concordance ${ }^{(10)}$.
There was no patient with normal gastric mucosa, contrasting with a previous study in children that reported normal gastric mucosa in $27.5 \%$ infected patients while examining fragments taken from antrum and fundus ${ }^{(9)}$. In addition, the mononuclear infiltrate was more intense than the neutrophilic infiltrate in most biopsies. This feature is often observed in children ${ }^{(12)}$. However, the mononuclear infiltrate in this study was more intense $(69.7 \%$ moderate/ severe) than that reported by COHEN et al. ${ }^{(5)}$, who described $65.8 \%$ of biopsies with mild to moderate mononuclear infiltrate. Other authors reported $87 \%$ of the biopsies with moderate to marked mononuclear infiltrate and $50 \%$ with moderate to intense neutrophilic infiltrate in children ${ }^{(22)}$. On the other hand, in another study up to $40 \%$ of the samples did not contain neutrophilic infiltrate ${ }^{(3)}$. The severity of the inflammatory changes in the gastric mucosa may have clinical significance, as more intense polymorphonuclear cell infiltrate was reported in patients with $H$. pylori gastritis associated with duodenitis than in infected patients without duodenitis ${ }^{(19)}$. It is possible that the high prevalence of active gastritis in all gastric regions observed in our study is related to the symptomatic children composing our study group.

Eosinophilic infiltrate was found in most patients $(95.5 \%)$. Eosinophil activation can occur in the context of the inflammatory response to $H$. pylori gastritis, because eosinophils are recruited with other polymorphonuclear cells like neutrophils. Thereafter, eosinophilic infiltrate is commonly seen in $H$. pylori gastritis in both children and adults, and the infiltrate is more severe in adults ${ }^{(22)}$. 
Antral nodularity is a very specific sign of $H$. pylori gastritis in children ${ }^{(17)}$, and it has been attributed to lymphoid follicles associated with the infection ${ }^{(16)}$. Surprisingly, in the present study there was no relationship between lymphoid aggregates and follicles and antral nodularity. Nodular gastritis has been associated with higher scores of gastritis ${ }^{(15)}$. Accordingly, we observed that antral nodularity was significantly associated with higher scores for both the polymorphonuclear cell infiltrate in the lesser curvature of the gastric antrum and the bacterial density in the gastric fundus. Antral nodularity is a clinically relevant condition because recently it has been associated with diffuse gastric cancer in young adults ${ }^{(13)}$ and it is also associated with duodenal ulcer in children ${ }^{(12)}$.

In the present study, up to one third of the patients presented lymphoid follicles in the gastric antrum (31.8\%), which is similar to the figures reported in H. pylori infected adults ${ }^{(22)}$. The meaning of lymphoid aggregates and follicles is not clear, but they are associated with the infection. Indeed, lymphoid aggregates and follicles are more prevalent in infected patients, and their prevalence decreases after successful eradication of the infection ${ }^{(4)}$.
No patients in this study exhibited gastric atrophy or intestinal metaplasia. However, other studies have reported a significant incidence of gastric atrophy $(42 \%-55 \%)$ and intestinal metaplasia (13\%-21\%) in children ${ }^{(11,14)}$. Interestingly, a higher incidence of atrophic gastritis has been observed in children from countries with high incidence of gastric cancer $^{(20)}$. Genetic and environmental factors other than $H$. pylori infection may explain the striking differences observed in the prevalence of these preneoplastic lesions in children from different countries.

In conclusion, most children and teenagers $(68.2 \%)$ with H. pylori gastritis exhibit active chronic gastritis without antral or corporeal predominance. The addition of a fragment from the gastric fundus to the panel proposed in the Updated Sydney System did not improve the diagnosis of the infection, or the diagnosis of preneoplastic histological abnormalities. Moreover, as no patient with gastric atrophy or intestinal metaplasia was identified in the present study, the histological evaluation of the infected children and adolescents may be restricted to the gastric antrum, as other authors have proposed ${ }^{(5)}$.

Langner M, Machado RS, Patrício FRS, Kawakami E. Avaliação da histologia gástrica em crianças e adolescentes com gastrite por Helicobacter pylori usando o Sistema de Sydney Atualizado. Arq Gastroenterol. 2009;46(4):328-32.

RESUMO - Contexto - Embora a infecção por Helicobacter pylori seja prevalente em nosso país, há poucos estudos avaliando a histologia gástrica de crianças infectadas. Objetivo - Avaliar as características histológicas da mucosa gástrica de crianças e adolescentes com gastrite por $H$. pylori. Métodos - Foram avaliadas 132 biopsias gástricas de 22 pacientes sintomáticos infectados por H. pylori (14F/8M, idade mediana 10 anos e 5 meses, variação: $2 \mathrm{a} 11 \mathrm{~m}$ a $16 \mathrm{a} 9 \mathrm{~m}$ ). As regiões gástricas avaliadas foram: antro (pequena e grande curvatura), corpo (pequena e grande curvatura), incisura angular e fundo. A avaliação histológica foi feita de acordo com o Sistema Sydney Atualizado. Foram gerados escores regionais do infiltrado de células polimorfonucleares, de células mononucleares e de densidade bacteriana. Resultados - Quinze (68,2\%) pacientes apresentaram gastrite crônica ativa associada a $H$. pylori, seis $(27,3 \%)$ apresentaram gastrite crônica ativa com predominância antral associada a $H$. pylori, e um (4,5\%), gastrite crônica ativa com predominância corpórea associada a H. pylori. Infiltrado de células polimorfonucleares e de mononucleares foram observados em, respectivamente $93,9 \%$ e $98,5 \%$ dos fragmentos de biopsia. Maior escore histológico de infiltrado de células polimorfonucleares, mononucleares e de densidade bacteriana foi observado no antro gástrico. Metaplasia intestinal e atrofia gástrica não foram observadas em nenhum paciente. Agregados linfóides e folículos linfóides foram observados no antro gástrico de três (13,6\%) e sete (31,8\%) pacientes, respectivamente, mas não foram associados à ocorrência de nodularidade antral. Conclusão - Gastrite crônica ativa foi observada em todos os pacientes com infecção por $H$. pylori. Na maioria dos pacientes não houve predominância antral ou corpórea da gastrite.

DESCRITORES - Gastrite, classificação. Infecções por helicobacter. Mucosa gástrica. Adolescente. Criança.

\section{REFERENCES}

1. Algood HM, Cover TL. Helicobacter pylori persistence: an overview of interactions between $H$. pylori and host immune defenses. Clin Microbiol Rev. 2006;19:597-613.

2. Amieva MR, El-Omar EM. Host-bacterial interactions in Helicobacter pylori infection. Gastroenterology. 2008;134:306-23.

3. Camorlinga-Ponce M, Aviles-Jimenez F, Cabrera L, Hernandez-Pando R, Munoz O, Soza J, Torres J. Intensity of inflammation, density of colonization and interleukin-8 response in the gastric mucosa of children infected with Helicobacter pylori. Helicobacter. 2003;8:554-60.

4. Chen XY, Liu WZ, Shi Y, Zhang DZ, Xiao SD, Tytgat GN. Helicobacter pylori associated gastric diseases and lymphoid tissue hyperplasia in gastric antral mucosa. J Clin Pathol. 2002;55:133-7.

5. Cohen MC, Cueto Rúa E, Balcarce N, Donatone J, Drut R. Assessment of the Sydney System in Helicobacter pylori-associated gastritis in children. Acta Gastroenterol Latinoam. 2000;30:35-40.

6. Cohen MC, Cueto Rúa E, Balcarce N, Drut R. Sulfomucins in Helicobacter pylori-associated chronic gastritis in children: is this incipient intestinal metaplasia? J Pediatr Gastroenterol Nutr. 2000;31:63-7.

7. Dixon MF, Genta RM, Yardley JH, Correa P. Classification and grading of gastritis. The Updated Sydney System. International Workshop on the Histopathology of Gastritis, Houston 1994. Am J Surg Pathol. 1996;20:1161-81.

8. El-Zimaity HM, Graham DY. Evaluation of gastric mucosal biopsy site and number for identification of Helicobacter pylori or intestinal metaplasia: role of the Sydney System. Hum Pathol. 1999;30:72-7.

9. Gottrand F, Cullu F, Turck D, Vincent P, Michaud L, Husson MO, MartinDelasalle E, Farriaux JP. Normal gastric histology in Helicobacter pylori-infected children. J Pediatr Gastroenterol Nutr. 1997;25:74-8.

10. Guarner J, Herrera-Goepfert R, Mohar A, Sanchez L, Halperin D, Ley C, Parsonnet J. Interobserver variability in application of the revised Sydney Classification for gastritis. Hum Pathol. 1999;30:1431-4.

11. Guarner J, Bartlett J, Whistler T, Pierce-Smith D, Owens M, Kreh R, Czinn S, Gold BD. Can pre-neoplastic lesions be detected in gastric biopsies of children with Helicobacter pylori infection? J Pediatr Gastroenterol Nutr. 2003;37:309-14

12. Hassall E, Dimmick JE. Unique feature of Helicobacter pylori disease in children. Dig Dis Sci. 1991;36:17-23. 
13. Kamada T, Tanaka A, Yamanaka Y, Manabe N, Kusunoki H, Miyamoto M, Tanaka S, Hata J, Chayama K, Harumaet K. Nodular gastritis with Helicobacter pylori infection is strongly associated with diffuse-type gastric cancer in young patients. Dig Endosc. 2007;19:180-4.

14. Kim KM, Oh YL, Ko JS, Choe YH, Seo JK. Histopathology and expression of Ki-67 and cyclooxygenase-2 in childhood Helicobacter pylori gastritis. J Gastroenterol. 2004;39:231-7.

15. Koh H, Noh TW, Baek SY, Chung KS. Nodular gastritis and pathologic findings in children and young adults with Helicobacter pylori infection. Yonsei Med J. 2007;48:240-6.

16. Luzza F, Pensabene L, Imeneo M. Antral nodularity and positive CagA serology are distinct and relevant markers of severe gastric inflammation in children with Helicobacter pylori infection. Helicobacter. 2002;7:46-52.

17. Machado RS, Viriato A, Kawakami E, Patrício FR. The regular arrangement of collecting venules pattern evaluated by standard endoscope and the absence of antrum nodularity are highly indicative of Helicobacter pylori uninfected gastric mucosa. Dig Liver Dis. 2008;40:68-72.
18. Ogata SK, Kawakami E, Patricio FR, Pedroso MZ, Santos AM. Evaluation of invasive and non-invasive methods for the diagnosis of Helicobacter pylori infection in symptomatic children and adolescents. São Paulo Med J. 2001;119:67-71.

19. Phull PS, Price AB, Stephens J, Rathbone BJ, Jacyna MR. Histology of chronic gastritis with and without duodenitis in patients with Helicobacter pylori infection. J Clin Pathol. 1996;49:377-80.

20. Ricuarte O, Gutierrez O, Cardona H, Kim JG, Graham DY, El-Zimaity HM. Atrophic gastritis in young children and adolescents. J Clin Pathol. 2005;58:1189-93.

21. Rugge M, Genta RM. Staging gastritis: an international proposal. Gastroenterology. 2005;129:1807-8.

22 Whitney AE, Guarner J, Hutwagner L, Gold BD. Helicobacter pylori gastritis in children and adults: comparative histopathologic study. Ann Diagn Pathol. 2000;4:279-85.

Recebido em 16/4/2008. Reapresentado em 4/11/2008

Aprovado em 10/3/2009 